Beyond Philology No. 16/3, 2019

ISSN 1732-1220, eISSN 2451-1498

https://doi.org/10.26881/bp.2019.3.04

\title{
Intercultural and global dimension of textbooks - points of consideration for language teachers
}

\author{
MARZANNA POGORZELSKA \\ SUSAN M. YELICH BINIECKI
}

Received 6.12.2018, received in revised form 7.08.2019, accepted 15.08.2019.

\begin{abstract}
As foreign language acquisition is potentially connected with shaping intercultural and global competences, this paper focuses on textbooks used for learning English to critically reflect on their diversityrelated contents. The conceptual frame of the research is based on specific aspects of intercultural and global education, connections between them, and learning English and the hidden curriculum. The qualitative study of textbook analysis content allowed the authors to identify main themes related to ethnic diversity, including petrification with exotization, and povertization. Thus, the findings of the study highlight the limitations in fostering intercultural and global values in the analysed material and stress both the need for critical approach in classroom practice and further study in this area with the use of a theoretical framework suggested by the authors.
\end{abstract}

\section{Keywords}

language learning, intercultural education, global dimension, textbooks 


\title{
Międzykulturowy i globalny wymiar podręczników - kwestie do refleksji dla osób uczących języka angielskiego
}

\begin{abstract}
Abstrakt
Biorąc pod uwagę, iż nauka języka obcego jest potencjalnie związana z kształtowaniem kompetencji globalnych i międzykulturowych, celem niniejszego artykułu jest krytyczna analiza treści zwiazanych $\mathrm{z}$ różnorodnością kulturową zawartych w podręcznikach używanych do nauki języka angielskiego. Rama teoretyczna analizy jest oparta na wybranych aspektach programu ukrytego, edukacji globalnej i międzykulturowej oraz związkach między nimi a nauka języka angielskiego. Jakościowe badanie treści podręczników pozwoliło autorkom zidentyfikować główne tematy zwiąane $\mathrm{z}$ różnorodnościa etniczna, określone jako petrification (petryfikacja), exotization (egzotyzacja) oraz povertization (ukazywanie osób i grup przez pryzmat ubóstwa). Wnioski płynące $z$ analizy dotyczą ograniczonego zakresu promowania wartości globalnych i międzykulturowych w badanym materiale, a także konieczności krytycznego podejścia w stosowaniu materiału dydaktycznych $\mathrm{w}$ praktyce edukacyjnej oraz potrzebe dalszych badań $\mathrm{w}$ tym zakresie $\mathrm{z}$ zastosowaniem ramy teoretycznej zaproponowanej w niniejszym tekście.
\end{abstract}

\section{Słowa kluczowe}

nauka języka obcego, edukacja międzykulturowa, wymiar globalny, podręczniki

\section{Introduction}

Foreign language acquisition has the natural potential to shape intercultural competencies, resulting primarily from the socio-cultural construction of a language (Byram 2013; Byram and Fleming 1998; Chamberlin-Quinlisk and Senyshyn 2012; Savva 2017). Various authors connecting intercultural issues with language learning emphasize cultural aspects of every act of communication and immersion of language in culture (Crozet and Liddicoat 1997; Hatoss 2004; Liddicoat 2005; Kramsch 
1993, 1998), which is expressed in Byram's remark that "One of the contributions of foreign language teaching to pupils' education is to introduce learners to and help them understand 'otherness"' (1989: 25). During foreign language learning, getting acquainted with this "otherness" is usually connected with the groups whose language is taught (e.g. the French, the Americans or the English). Rarely is it considered that foreign language acquisition provides various opportunities to get in touch with cultures other than the ones directly related to the target language.

Acknowledging the potential intercultural importance of learning languages, this paper critically analyzes the depiction of particular groups of non-European origin in the chosen sample of textbooks used in teaching English in Poland. The choice of textbooks as the subject of the analysis results from the fact that whatever subject they serve, they are still an inevitable part of formal education, carrying and embedding the set of norms and values preferred in a given society (Apple and Christian-Smith 1991; Chomczyńska-Rubacha 2011; Meighan 1993; Pingel 2010; Stawowy 1995; Schissler 1989-1990; Woodward 1994). Therefore, the findings of this paper can inform the practice of language teachers as they approach the presentation of culture related content within texts.

First, the conceptual framework and the research questions guiding the analysis will be presented. This part will be followed by the methodology, findings, and conclusions.

\section{Conceptual framework and the research question}

The conceptual framework of the paper integrates the concepts of intercultural and global education in relation to foreign language teaching and hidden curriculum-related issues.

Intercultural education, defined as a means of fostering intercultural competencies, has a transformative and emancipatory character in which learners form the ability to question their own ethnocentric attitudes, valuing cultural diversity and equality (Bennett 1993; Brander 1995; Byram 1997; Huber et 
al. 2014; Grzybowski 2008; Jackson 2008; Nikitorowicz 2007; Powell and Powell 2010). "Equality" within intercultural education is related to "getting rid of domination and privilege of normality, i.e. assuming that our own system of values and ways of thinking is obvious, self-evident and non-discussable" (Szkudlarek 2003: 23). Contesting and critically reflecting upon one's own point of view and position in social structures can be both inspiring and challenging within educational settings (Brookfield 2017). The concept of intercultural education is tightly connected with areas of global education which "is an active learning process based on the universal values of tolerance, solidarity, equality, justice, inclusion, co-operation and non-violence" (Global Education Guide 2009: 3). Global education, among different objectives, is aimed at making learners understand complex diversity of today's world, where different groups are interconnected and interrelated and where critical skills, including the ability to recognize stereotypes and prejudices, help learners appreciate this diversity (da Silva 2010: 23-24).

The need for intercultural and global dimensions in education is included in the main documents from the Polish Ministry of Education regulating the functioning of schools in Poland, which oblige schools to teach "openness to values of European and world cultures, [...] solidarity, democracy, justice and freedom" (Ustawa o systemie oświaty 1991: 1), support "friendship among people of different nations, races and opinions" (Karta Nauczyciela 1982: 5), shape respect for other cultures and traditions, and take necessary steps to prevent any discrimination (Podstawa programowa $z$ komentarzami 2008: 3; Podstawa programowa 2012: 75).

Hatoss emphasizes that intercultural learning during language acquisition should avoid an ethnocentric approach and the promotion of stereotypes (2004). She suggests a checklist for examining cultural contents in language textbooks with questions related to whether the textbooks refer only to "surface culture (e.g. food, dressing, and other visible elements of culture)" or also "deep culture (orientations, values, non-visible 
and non-tangible elements of culture)" and whether they represent culture as "monolithic" or "dynamic", and cater for "the atypical and individual" (2004: 32). The question of textbooks' intercultural contents also has been discussed in UNESCO documents referencing "a lack of diversity" and criticism of some textbooks "for stereotypical, simplistic interpretations of ethnic, cultural, religious and linguistic minorities" (Policy paper 28: 9). Similarly, the guidelines on global education, particularly the ones focusing on presenting the global South, emphasize the need of avoiding stereotypes and presenting this region against a broad context as culturally, socially and politically diverse (Gontarska et al. 2015).

Finally, lenses of a hidden curriculum, defined as "unintended outcomes of the schooling process" (McLaren 2009: 75) inform the conceptual framework for analysis. According to different authors, the concept of hidden curriculum is a tool of highlighting and deconstructing these elements of the educational system that contribute to perpetuating stereotypes and petrifying social inequalities (Bourdieu and Passeron 1990; Chomczyńska-Rubacha and Pankowska 2011; Janowski 1989; McLaren 2009; Meighan 1993). Connecting the issue of a hidden curriculum and textbooks, Meighan described a classroom as the place "haunted" by the ghosts of the textbooks' authors with all their infirmities and prejudices (1993: 75-76). For an American context, it might be useful to mention here Banks and Banks, who in relation to American reality, stated that "historically, textbooks were written by members of powerful mainstream groups. In the United States, they have been written primarily by white, Protestant, middle- or upper-class men" (2013: 2061). In Poland, authors of one of the most comprehensive studies so far related to textbooks (designed for Polish, History, Knowledge of Society, Preparation for Family Life) conclude that texts insufficiently represent contemporary diversity, promote a Europocentric approach, and lack issues facilitating the debate on stereotypes, prejudices, and discrimination (Pawlęga and Chustecka 2011; Jonczy-Adamska 2011). Authors of other publications, focusing on the analysis of glob- 
al education elements in textbooks, point out the global South often is presented in a stereotypical and simplified way, in which poverty, wildness and traditionalism are the most distinctive features of this part of the world (Kielak et al. 2016; Popow 2015).

Relying on the chosen aspects of intercultural and global education and their connections with learning English, there were two main research questions that guided this examination: 1) What image of groups of non-European origin is depicted in the chosen sample of textbooks used by English teachers and learners in Poland, 2) In what ways, if at all, does this image contribute to values of intercultural and global education? Finally, conducting the analysis was aimed at raising language teachers' awareness of potentially stereotypical and simplified depiction of these groups on the pages of educational materials.

\section{Methodology}

The educational material examined in the present research consists of English textbooks used in Polish upper secondary schools. ${ }^{1}$ Eight out of nine examined textbooks were published by UK-based publishing houses. The choice of particular textbooks (see bibliography for details) was based on their popularity in the biggest internet shops representing publishing houses in Poland. This choice was confirmed by 3 interviews with Polish teachers of senior secondary schools. Six textbooks represented a pre-intermediate level designed to prepare for the Matura examination, the final comprehensive examination for senior secondary school, on a basic level and three represented an intermediate level for preparation for the advanced Matura level.

\footnotetext{
1 These schools are attended by about $80 \%$ of young people after junior secondary school (Vulcan 2017; GUS 2015) and they finish with the Matura exam that can be taken at basic level (chosen by $92 \%$ of students) and advanced level (chosen by $51 \%$ of students) (CKE 2017). Thus, the chosen books are not only aimed at teaching the language, but they are also a commonly used tool preparing for Matura examination.
} 
The analysis is a qualitative study based on an interpretive research approach with a central importance on the meaningmaking process (Bhattacharya 2008; Sławecki 2012). In the research, the focus was given to the textbook depiction of the groups identified as of non-European origin and considered to be native inhabitants of Africa, Asia, Australia, New Zealand, other Pacific islands, the Caribbean, North and South America (all these groups will be referred to as target groups). The units of the analysis were parts of the books understood as a logical unity: a piece of article, a poem or a dialogue in case of texts. The chosen texts were subject to content analysis with a coding process that allowed the authors to identify recurring patterns and defining final themes that emerged from the research (Babbie 2003; Gibbs 2007; Kubinowski 2010; Lichtman 2006).

\section{Findings}

(Note: Quotations from the textbooks are followed by the number of the textbook they come from and relevant pages. The numbers assigned to each textbook are placed in the end of the text).

In all the analyzed textbooks, the target groups coming from the regions listed below were identified - the numbers in the brackets stand for the number of texts in which the representatives of the given location were present: Africa (11), Asia (23), Australia, New Zealand and Pacific islands (11), the Caribbean (5), North and South America (6). The common patterns that emerged from the analysis were classified by the authors in two interrelated themes defined as petrification with exotization and povertization of ethnicity. Before the detailed explanation of these two themes, descriptive data is depicted in Table 1 , which show the prevalence of these images in depicting the target groups. 
Table 1

Number of target groups classified within the categories

\begin{tabular}{|l|c|c|}
\hline $\begin{array}{c}\text { Region with the } \\
\text { number of } \\
\text { references to the } \\
\text { target groups }\end{array}$ & $\begin{array}{c}\text { Number of target } \\
\text { groups classified } \\
\text { within the category: } \\
\text { petrification with } \\
\text { exotization }\end{array}$ & $\begin{array}{c}\text { Number of target } \\
\text { groups classified } \\
\text { within the category: } \\
\text { povertization }\end{array}$ \\
\hline Africa (11) & 7 & 4 \\
\hline $\begin{array}{l}\text { Australia, New } \\
\text { Zealand and other } \\
\text { Pacific Islands (11) }\end{array}$ & 11 & - \\
\hline Asia (23)* & 22 & - \\
\hline the Caribbean (5) & 5 & - \\
\hline $\begin{array}{l}\text { North and South } \\
\text { America (6) }\end{array}$ & 6 & - \\
\hline
\end{tabular}

* In one case the target group (Chinese) did not fall into any category being mentioned as the group on which experiments were confirmed $(3,39)$.

The results show that the dominating image of target groups is related to presenting them through their past and traditional lifestyle with a few references to poverty these groups experience. At the same time, the image that could counterbalance this type of depiction is practically non-existent on the pages of the chosen textbooks.

\subsection{Petrification with exotization of target groups}

Petrification, taking place when diverse-groups are presented through their past, and exotization, as referring to their very traditional habits that are highlighted, are interconnected issues. Because of the integrated nature, the concepts were identified as one theme.

As for presenting some groups in reference to their past, in some cases (Aborigines, Egyptians, Eskimos, Maoris, native North Americans) the past is actually the only way people appear on textbook pages. In other cases, e.g. Indians or Jamai- 
cans, a historical context constitutes their image to a substantial degree. The association of the group with the past is created either by adding the relevant adjective (e.g. "Ancient Egyptians" and "Ancient Eskimos", 3,131 ) or connecting the description with a colonial context (e.g. presentation of Maori people as the ones who in 1840 "accepted British rule", 8, 63 or Hawaiians as guilty of killing Captain Cook in 1779, 6, 118). These past references are frequently related to superficial and practical aspects of life, not deeper cultural achievements or values these groups might have created, e.g.: "The Aztecs and Incas ate a lot of cereals, beans and fruit and not much meat at all" $(1,59)$, "Europeans learned to use the sweet sap of the sugar maple tree from Canadian Indians [...]. Many of the first settlers were fur traders who bought beaver skins from native hunters" $(6,192)$. Moreover, the image of target groups is very simplified and stereotyped, like the one concerning the first inhabitants of Jamaica, "peaceful tribes of Taino and Arawak" who "lived in huts, slept in hammocks, and caught fish with simple stone-tipped spears" $(8,132)$ or the native North Americans, "a peace-loving people who enjoyed a simple life, [...] farmed the land, fished, and hunted wild animals" $(8,132)$. In fact, an equally stereotyped picture is presented in reference to the present: Jamaicans "take great pleasure in debating" $(7,253)$ while "Indians are demanding in terms of eating etiquette" $(7,256)$. Although such cliched phrases also refer to other groups, including the ones of European origin, they are, in European cases, always counterbalanced by numerous diverse representations.

This petrified and exotic image of ethnicity lacks references to the processes of development and transformation the target groups have undergone. This alleged unchanged lifestyle, similarly as it takes place in case of presenting the past, refers to superficial elements of culture, usually appearance, eating habits or accommodation to quote just a few examples:

Traditional customs, like tattooing, head-shaving, piercing or other kinds of body modification can express status, identity or be- 
liefs. In Borneo, for instance, tattoos are like a diary because they are written record of all important events and places a man has experienced in his life. For New Zealand's Maoris they reflect the person's position in society. In western society, where tattoos used to be considered a sign of rebellion, the culture is changing and they are now a very popular form of body art $(4,4)$.

While travelling, Gordon has found out that people in most parts of the world eat in sects. Only the cultures of Europe are exceptions. People in the Middle East dine on locust [...], Africans and South Americans collect ants and termites for food [...] Cambodians eat "deep-fry spiders" $(7,208)$.

Many Brazilians living along the mighty Amazon river live in stilt houses, as they know that it is the only way to prevent their homes from being destroyed by water when the Amazon floods. [...] In the mountainous Hunan Province in China, the Han, Tujia, Miao, Hui, Dong and Zhuang peoples have managed to inhabit the steep mountains by building stilt houses $(8,18)$.

The first of the above quotations refers to appearance. In general, ideals of beauty within Europe are depicted as continuously changing while permanently stuck in other parts of the world. This message is strengthened by the illustrations in which target groups are always presented with very traditional face painting, jewellery or masks while European representations vary from the images of Rubens ideal, through Elizabethan England, Coco Chanel to Beckhams $(4,4 ; 3,106)$.

Finally, the groups of non-European origin are frequently shown in the context of holidays or events they celebrate, like Indians and a Kite Festival $(7,264)$, a New Zealand rugby team performing "the Haka, an intimidating Maori Warrior dance" $(8,63)$, Chinese celebrating New Year $(7,165)$ or Jewish people during Hanukkah $(7,165)$.

Although the analysis did not include the target groups living outside their native regions, it is worth noticing (and maybe for future analysis), that many of them were presented as belonging to minorities, as in the description of modern Britain 
where "The largest minority groups are Indian, Pakistani, Black African, Black Caribbean and Chinese" $(6,92)$ or the USA whose "population consists of almost $80 \%$ people of European origin [...], $12.85 \%$ African origin, 4.5\% Asian" $(8,133)$. Factual as it is, such statements close the given groups within the concept of eternal minority, detached from mainstream groups.

\subsection{Povertization of the target groups}

Depicting target groups through poverty they experience refers to the groups of African origin, which are associated with hunger, illnesses, poor healthcare and education, lack of water and other basic needs. At the same time, the stories of these people are accompanied by the information about different charities or campaigns, of European, mainly British origin, which bring a solution and relief to the suffering people while native people are grateful, but passive receivers of help. The representative piece of such texts is the one titled If they hadn't owned a goat... about Beatrice:

[...] her mother and her seven brothers and sisters lived in a small village in Uganda. They were very poor and basic necessities were a luxury. [...] When Beatrice was nine, a life-changing event happened to them. The family was given a goat by a small charity called Heifer International. Within three months of receiving the goat, Beatrice and her family had raised enough money from the sale of the goat's milk to send Beatrice to school. [...] Beatrice has many people to thank for their support and encouragement along the way. But most of all, she's grateful to that first goat $(4,96)$.

Similar stories refer to Mozambique ("one of the poorest countries in Africa" with "two qualities that appealed to them: great potential as a travel destination and local people who desperately needed help") and the NEMA charity that provided the poor area with schools, clean water and built the tourist resort (4, 16-17). The repeating pattern traceable in these texts includes on one side information about the whites who have the 
ideas, power, and determination and on the other hand, relatively passive native inhabitants:

Life in Guludo was hard: there was little clean water and not enough food. Healthcare was poor and people in the village had a life expectancy of thirty-eight years. Amy and Neal had no qualifications in tourism or healthcare but they had common sense, enthusiasm and determination. They talked to the villagers about their plan to create a small beach resort which would provide employment for people and lift families out of poverty [...]. The couple set to work on a beach lodge building beach huts from local materials and employing people from the surrounding area $[\ldots]$ they set up a charitable foundation $(4,16-17)$.

The whites, even without experience, seem to have a magical power to save and change the lives of the ones in need, like Amy Carter-James: a "small, blue-eyed and blonde" who "doesn't look like she could change the lives of thousands of people but, remarkably, she has" (4, 16-17). Similar examples refer to a story about another charity, Sport Relief, illustrated by the example of Mohammed Koroma from Sierra Leone mentioned as the grateful receiver of help $(4,48-49)$ or a story of Asian (no country is given) Buddhist monks who are students taught by the girl from Great Britain, $(2,32)$.

\section{Conclusions}

According to both of the official documents defining the objectives of educational policy in Poland and in Europe (Ustawa o systemie oświaty1991; Karta Nauczyciela 1982; Podstawa programowa $z$ komentarzami 2008; Eur-lex 2006) and the main assumptions of an intercultural and global education approach to teaching, education should promote openness, equality, tolerance and shape respect for other cultures and traditions. Having analyzed the sample of textbooks and their contents devoted to depiction of the chosen groups of nonEuropean origin, this study suggests that the examined mate- 
rial may not be a strong resource for fostering the values of intercultural and global education.

Presenting target groups through their past history or traditional customs, as cultural curiosity stuck in tribal rituals and lifestyles, only solidifies already existing stereotypes and images of the Other as a stranger. In addition, showing some groups only through the prism of the poverty they experience, does not contribute to intercultural understanding as their immobilization in this poor condition does not open the possibility to perceive them as self-efficient and empowered human beings. At the same time, there is no doubt hunger and poverty are huge problems in developing countries, but limiting their reality only to this issue strengthens the stereotype of helpless citizens whose lives depend on Western world mercy. Although it remains unquestionable that many charities do a necessary job, presenting cultural groups without a broader context that very often is connected with prior Western devastation of resources, gives the impression of the immobilized global South existing thanks to the support of the resourceful and active North. Such a picture is far from reality as it neglects development and modernity that takes place in some countries of the regions mentioned. It is also worth noting that the pages of textbooks are populated mainly by white British or Americans who, contrary to the target group representatives, conduct ordinary lives and perform a variety of activities (shopping, dating, working) or are the representatives of literature, art, politics or science.

Although similar studies have analyzed history and civic education textbooks, this study focuses on English as a foreign language textbooks, which is quite unique particularly in the context of intercultural and global content. If language textbooks are being analyzed, it is usually their usefulness as language teaching tool that is researched, not cultural diversity, ethnicity or other related issues. In the case of Poland and other post-communist countries, the textbook analyses have been concentrated mainly on a gender dimension, whereas the 
issues of nationality or ethnicity, especially in reference to language textbooks, are practically absent.

In the presented research, the choice of textbooks was limited to the ones used in secondary schools. Future research could broaden the scope of this exploration to comprise the material used in earlier stages of education. Moreover, the study does not focus on a gender dimension, which would additionally enrich the contents of the analysis.

Findings in this study challenge the belief that teaching English as a foreign language "automatically" fosters intercultural understanding. It is important for educators to sensitize themselves and their learners to be aware of the hidden meaning that often resides from intercultural education objectives. These conclusions might be inspiring for educators, teachers and educational decision-makers to critically reflect and analyse textbook contents in order to complement the books as well as use the texts in a critical way to deconstruct stereotypes and biased opinions they often perpetuate.

\section{References}

Apple, Michael, Linda Christian-Smith (eds.) (1991). The Politics of the Textbook. New York - London: Routledge.

Babbie, Earl (2003). Badania spoleczne w praktyce. Warszawa: Wydawnictwo Naukowe PWN.

Banks, James, Cherry A. McGee Banks (2013). "Textbook treatment of ethnic groups". In: Carlos E. Cortes (ed.). Multi-cultural America: A Multimedia Encyclopaedia. Thousand Oaks: Sage Publications, 2061-2065.

Bennett, Milton (1993). "Towards a developmental model of intercultural sensitivity". In: Michael Paige (ed.). Education for Intercultural Experience, Yarmouth, ME: Intercultural Press, 21-71.

Bhattacharya, Himika (2008). "Interpretive research". In: Lisa Given (ed.). The SAGE Encyclopedia of Qualitative Research Methods. Thousand Oaks: Sage Publications, 465-467.

Bourdieu, Pierre, Jean-Claude Passeron (1990). Reprodukcja: Elementy teorii systemu nauczania. Warszawa: Państwowe Wydawnictwo Naukowe. 
Brander, Pat, Carmen Cardenas, Juan de Vincente Abad, Rui Gomes, and Mark Taylor (1995). All Different, All Equal: Education Pack. Strasbourg: Council of Europe.

Brookfield, Stephen (2017). Becoming a Critically Reflective Teacher. San Francisco, CA: Jossey-Bass.

Byram, Michael (1989). Cultural Studies in Foreign Language Education. Clevedon - Philadelphia: Multilingual Matters.

Byram, Michael, Mike Fleming (eds.) (1998). Language Learning in Intercultural Perspective. Approaches through Drama and Etnography. Cambridge: Cambridge University Press.

Byram, Michael (1997). Teaching and Assessing Intercultural Communicative Competence. Clevedon: Multilingual Matters.

Byram, Michael (2013). "Foreign language teaching and intercultural citizenship". Iranian Journal of Language Teaching Research 1/3: 53-62.

Chamberlin-Quinlisk, Carla, Roxanna Senyshyn (2012). "Language teaching and intercultural education: Making critical connections". Intercultural Education 23/1:15-23.

Chomczyńska-Rubacha, Mariola (ed.) (2011). Podręczniki i poradniki: Konteksty. Dyskursy. Perspektywy. Kraków: Oficyna Wydawnicza Impuls.

Chomczyńska-Rubacha, Mariola, Dorota Pankowska (2011). "Władza, ideologia, socjalizacja. Polityczność podręczników szkolnych". In: Mariola Chomczyńska-Rubacha (ed.). Podręczniki i poradniki: Konteksty. Dyskursy. Perspektywy. Kraków: Oficyna Wydawnicza Impuls, 17-30.

CKE (2107). Centralna Komisja Egzaminacyjna. Available at <https: // www.cke.edu.pl/egzamin-maturalny/>. Accessed 7.08.2019.

Crozet, Chantal, Anthony Liddicoat (1997). "Teaching culture as integrated part of language teaching: An introduction". Australian Review of Applied Linguistics 14: 1-22.

da Silva, Miguel Carvalho (2010). Global Education Guidelines: A Handbook for Educators to Understand and Implement Global Education. Lisbon: The North-South Centre of the Council of Europe.

Eur-lex (2006). Lifelong Learning - Key Competences. Available at $<$ http://eur-lex.europa.eu/legal-content/EN/TXT/?uri=LEGISSU M\%3Ac11090>. Accessed 7.08.2019.

Gontarska, Maria, Elżbieta Kielak, Anna Huminiak, Anna Kucińska, Magda Quandil (2015). Jak mówić o większości świata? Jak rze- 
telnie informować o krajach globalnego Południa? Warszawa: Instytut Globalnej Odpowiedzialności.

Gibbs, Graham (2007). Analyzing Qualitative Data. London: Sage Publications.

Global Education Guide (2009). Global Education Network of Young Europeans. Available at <http://glen-europe.org/wp-content/ uploads/2010/11/GLEN-GE-Guide-2009.pdf>. Accessed 7.08.2019.

Grzybowski, Pawel (2008). Edukacja międzykulturowa - przewodnik. Pojęcia - literatura-adresy. Kraków: Impuls.

GUS (2015). Oświata $i$ wychowanie $w$ roku szkolnym 2014- 2015. Warszawa: GUS. Available at <https://stat.gov.pl/files/gfx/portal informacyjny/pl/defaultaktualnosci/5488/1/9/1/oswiata_i_wych owanie_w_roku_szkolnym_2014-2015.pdf>. Accessed 7.08.2019.

Hatoss, Aniko (2004). "A model for evaluating textbooks". Babel 39: 25-32.

Huber, Josef, Christopher Reynolds, Martyn Barrett, Michael Byram, Ildikó Lázár, Pascale Mompoint-Gaillard, Stavroula Philippou (eds.) (2014). Developing Intercultural Competence through Education. Strasbourg: Council of Europe.

Jackson, Robert (2008). "Religious and cultural diversity: Some key concepts". In: John Keast (ed.). Religious Diversity and Intercultural Education: a Reference Book for Schools. Strasbourg: Council of Europe, 21-30.

Janowski, Andrzej (1989). Uczeń $w$ teatrze życia szkolnego. Warszawa: Wydawnictwa Szkolne i Pedagogiczne.

Jonczy-Adamska, Małgorzata (2011). „Analiza i podstawy programowej - przedmiot wiedza o społeczeństwie." In: Marta Abramowicz (ed.). Wielka nieobecna - o edukacji antydyskryminacyjnej $w$ systemie edukacji formalnej $w$ Polsce. Warszawa: TEA, 188-226.

Karta Nauczyciela (1982). Karta Nauczyciela. Ustawa z dnia 26 stycznia 1982 r. Dz.U. 1982 nr 3 poz. 19. Warszawa: Sejm RP.

Kielak, Elżbieta, Dominika Cieślikowska, Anna Kudarewska (2016). Edukacja globalna $w$ podręcznikach do geografii i wiedzy o społeczeństwie. Raport $z$ analizy wybranych podręczników szkolnych pod katem założeń edukacji globalnej. Warszawa: Grupa Zagranica.

Kramsch, Claire (1993). Context and Culture in Language Education. Oxford: Oxford University Press.

Kramsch, Claire (1998). Language and Culture. Oxford: Oxford University Press. 
Kubinowski, Dariusz (2010). Jakościowe badania pedagogiczne: Filozofia - metodyka - ewaluacja. Lublin: Wydawnictwo Uniwersytetu Marii Curie-Skłodowskiej.

Lichtman, Marilyn (2006). Qualitative Research in Education: A User's Guide. London - New Delhi: Thousand Oaks.

McLaren, Peter (2009). "Critical pedagogy: A look at the major concepts". In: Antonia Darder, Marta Baltodano, Rodolfo Torres (eds.). The Critical Pedagogy Reader. New York - London: Taylor \& Francis, 61-83.

Meighan, Roland (1993). Socjologia edukacji. Toruń: Uniwersytet Mikołaja Kopernika.

Nikitorowicz, Jerzy (2007). Edukacja międzykulturowa - kreowanie tożsamości dziecka. Gdańsk: Gdańskie Wydawnictwo Psychologiczne.

Pawlęga, Michał, Magdalen Chustecka (2011). "Analiza podręczników i podstawy programowej - przedmiot język polski”. In: Marta Abramowicz (ed.). Wielka nieobecna - o edukacji antydyskryminacyjnej $w$ systemie edukacji formalnej $w$ Polsce. Warszawa: TEA, 116-158.

Pingel, Falk (2010). UNESCO Guidebook on Textbook Research and Textbook Revision. Second revised and updated edition. Paris Braunschweig: UNESCO.

Podstawa programowa $z$ komentarzami (2008). Języki obce $w$ szkole podstawowej, gimnazjum i liceum. Tom 3. Warszawa: MEN.

Podstawa programowa (2008). Podstawa programowa ksztakcenia ogólnego dla gimnazjów i szkót ponadgimnazjalnych, których ukończenie umożliwia uzyskanie świadectwa dojrzałości po zdaniu egzaminu maturalnego (załącznik nr 4 do Rozporzadzenia Ministra Edukacji Narodowej z dnia 23 grudnia 2008 r. $w$ sprawie podstawy programowej wychowania przedszkolnego oraz ksztakcenia ogólnego w poszczególnych typach szkót (Dz. U. Nr 4 poz.17). Warszawa: MEN.

Podstawa programowa (2012). Rozporzadzenie Ministra Edukacji Narodowej z Dnia 27 sierpnia 2012 r. $w$ Sprawie podstawy programowej wychowania przedszkolnego oraz kształcenia ogólnego w poszczególnych typach szkót (Dz. U. z 2012 r. poz. 977).

Policy paper 28 (2016). Textbooks pave way to sustainable development. Available at <http://unesdoc.unesco.org/images/0024/ 002467/246777E.pdf >. Accessed 7.08.2019.

Popow, Monika (2015). "Globalna Północ i Globalne Południe w dyskursie edukacyjnym: Krytyczna analiza treści podręczników 
szkolnych". Studia Edukacyjne 35: 251-273. Available at: DOI: 10.14746/se.2015.35.14.

Powell, Robert, Dana Powell (2010). Classroom Communication and Diversity: Enhancing Instructional Practice. New York - London: Routledge.

Savva, Maria (2017). "Learning to teach culturally and linguistically diverse students through cross-cultural experiences". Intercultural Education 28/3: 269-282.

Schissler, Hanna (1989-1990). "Limitations and priorities for international social studies textbook research". The International Journal of Social Education 4: 81-89.

Sławecki, Bartosz (2012). „Znaczenie paradygmatów w badaniach jakościowych". In: Dariusz Jemielniak (ed.). Badania jakościowe: Podejścia i teorie. Warszawa: Wydawnictwo Naukowe PWN, 57-87.

Stawowy, Ewa (ed.) 1995. Wartości $i$ manipulacje $w$ podręcznikach szkolnych. Kraków: Oficyna Wydawnicza Impuls.

Szkudlarek, Tomasz (2003). "Pedagogika międzykulturowa". In: Zbigniew Kwieciński, Bogusław Śliwerski (eds.). Pedagogika: Podręcznik akademicki. Warszawa: Wydawnictwo Naukowe PWN, 415-424.

Ustawa o systemie oświaty (1991). Ustawa $z$ dnia 7 września 1991 o systemie oświaty. Dz.U. 1991 nr 95 poz. 425. Warszawa: Sejm RP.

Vulcan (2017). Available at <https://www.vulcan.edu.pl/razem/blog/ show/gimnazjalisci-zbliza-sie-czas-wyboru-szkoly-23>. Accessed 06.12.2018.

Woodward, Arthur (1994). "Textbooks". In: Torsten Husen, Neville Postletwhaite (eds.). The International Encyclopedia of Education. New York - London: Taylor \& Francis, 6366-6371.

\section{Examined textbooks}

1. McKinlay, Stuart, Bob Hastings, Beata Trapnell, Tomasz Siuta, Catherine Bright (2014). My Matura Success Pre-intermediate Students' Book. London: Pearson Education.

2. Cunningham, Sara, Peter Moor, Marta Umińska (2009). Real Life Pre-intermediate Students' Book. London: Pearson Education.

3. McKinlay, Stuart, Bob Hastings, Beata Trapnell, Regina Raczyńska, Catherine Bright (2014). My Matura Success Intermediate Students' Book. London: Pearson Education.

4. Wildman, Jayne, Cathy Myers, Claire Thacker (2013). Insight Intermediate Students' Book. Oxford: Oxford University Press. 
5. Umińska, Marta, Bob Hastings, Dominika Chandler, Rod Fricker, Angela Bandis, Beata Trapnell (2014). Repetytorium maturalne, poziom podstawowy / Matura Revision Course - Basic Level. London: Pearson Education.

6. Umińska, Marta, Bob Hastings, Dominika Chandler, Rod Fricker, Angela Bandis, Beata Trapnell (2014). Repetytorium maturalne, poziom rozszerzony / Matura Revision Course - Advanced Level. London: Pearson Education.

7. Inglot, Marta, Anna Milewska, Katarzyna Mrozowska-Linda, Zbigniew Pokrzewiński, Beata Polit, Anna Rzeźnik, Agnieszka Saramowicz-Garstecka, Halina Tyliba, Stephen Davies (2014). Destination: Matura 2015 Repetytorium dla szkół ponadgimnazjalnych: Poziom podstawowy. Warszawa: Nowa Era.

8. Evans, Virginia, Jenny Dooley (2011). Express Publishing Matura repetytorium: Poziom podstawowy. Berkshire: Express Publishing, Egis.

9. Manin, Gregory, Danuta Gryca, Joanna Sobierska, Joanna Sosnowska (2014). Oxford Matura Trainer Poziom podstawowy: Repetytorium z języka angielskiego: Podręcznik dla szkół ponadgimnazjalnych. Oxford: Oxford University Press.

\author{
Marzanna Pogorzelska \\ Opole University \\ Faculty of Philology \\ Institute of English \\ Plac Kopernika 11 \\ 45-040 Opole \\ Poland \\ mpogorzelska@uni.opole.pl \\ Susan M. Yelich Biniecki \\ Kansas State University \\ College of Education \\ Department of Educational Leadership \\ Adult Learning and Leadership Program \\ 61 Bluemont Hall \\ Manhattan \\ Kansas 66506 \\ U.S.A. \\ susanyb@ksu.edu
}

